\title{
«СЛОВО ГОДА» КАК КУЛЬТУРОЛОГИЧЕСКИЙ ФЕНОМЕН НЕОЛОГИЗАЦИИ АНГЛИЙСКОГО ЯЗЫКА НА СОВРЕМЕННОМ ЭТАПЕ ЕГО РАЗВИТИЯ (НА ПРИМЕРЕ БРИТАНСКОЙ И АМЕРИКАНСКОЙ ВЕРСИЙ ИЗДАТЕЛЬСТВА ОКСФОРДСКОГО УНИВЕРСИТЕТА)
}

\begin{abstract}
"WORD OF THE YEAR" AS A CULTURAL PHENOMENON OF NEOLOGIZATION

OF THE ENGLISH LANGUAGE AT THE

PRESENT STAGE OF ITS DEVELOPMENT

(ON THE EXAMPLE OF THE BRITISH AND AMERICAN VERSIONS OF THE OXFORD UNIVERSITY PRESS)
\end{abstract}

M. Mikhaylov

Ju. Mikhailova

Summary: The article considers the cultural phenomenon of the national "word of the year» as one of the ways to enlarge the vocabulary of the language. The mechanism of neologization of the "words of the year" in the English language is analyzed, options for the "words of the year" according to the American and British versions of the Oxford University Press are considered.

Keywords: language, neologism, "word of the year», vocabulary, neologization.

\author{
Михайлов Михаил Романович \\ К.т.н., дочент, Орловский государственный аграрный \\ университет имени Н.В. Парахина \\ mmichailov@mail.ru \\ Михайлова Юлия Люсиевна \\ К.филол.н., Орловский государственный аграрный \\ университет имени Н.В. Парахина \\ julia_mchailova@mail.ru
}

Аннотация: В статье рассматривается культурологический феномен национального «слова года» как один из способов пополнения словарного состава языка. Анализируется механизм неологизации «слов года» в английском языке, рассматриваются варианты «слов года» по американской и британской версии издательства Оксфордского университета.

Ключевые слова: язык, неологизм, «слово года», лексический состав, неологизация.
В 21-м веке мы наблюдаем ускорение темпов развития всех областей человеческой деятельности - как в технической сфере, что уже дало рост объема информации в геометрической прогрессии, так и в развитии общества, социальной и культурной сфере, что находит свое отражение в изменении лексического состава языка, в первую очередь за счёт пополнения его состава, а именно - введения в речь новых лексических единиц - неологизмов. Неологизация является одним из основных способов пополнения лексического строя современного языка. Выделяют лексические и семантические, фонологические и морфологические неологизмы, собственно неологизмы, трансноминации и переосмысления, семантические инновации [1, с.129].

Одним из явлений, которые отражают этот процесс, является акция «слово года» - слово, словосочетание или выражение, которое является наиболее значимым, популярным или актуальным, и которое вошло в обиход в данном году. В зависимости от страны, его выбор осуществляется либо экспертным жюри, либо общественным опросом. В настоящее время акция проводит- ся на разных языках: английском - «Word of the year» в Великобритании, США и Австралии; немецком - «Wort des Jahres» в Германии (самой Германии и Саксонии), Австрии, Швейцарии, Лихтенштейне и итальянской провинции Верний Тироль; датском - «А̊rets ord» В Дании, русском - «Слово года» в России, украинском - «Слово року» в Украине, японском - «Иероглиф года» (今年の漢 字 Котоси-но кандзи - яп.) и некоторых других языках. Обычно это мероприятие проводится в декабре-январе, и включает в себя как «слово года» и «выражение года», которые имеют актуальное значение и отражают позитивные тенденции, так и «антислово» и «антивыражение года», появившиеся в течение того же периода явления, которые вошли в словоупотребление, имеют достаточно большую частотность употребления, но, что более важно, имеют значительный резонанс и ярко иллюстрируют настроения в обществе.

Традиция выбора «слова года» была заложена в Германии в 1971 году, когда одно из наиболее авторитетных немецких языковых обществ «Gesellschaft für deutsche Sprache» («Общество немецкого языка») предложило в 
качестве «слова года» прилагательное "aufmüpfig" - мятежный, непокорный. Изначально данное слово употреблялось в южно-немецком диалекте Баварии и Австрии и пришло в язык немецких СМИ в начале 70-х годов, отражая процессы, происходившие в немецком обществе в то время, позднее оно было принято в состав литературного немецкого языка, получив дополнительное значение. С 1977 года выбор «слова года» немецким языковым обществом стал ежегодным, с 1991 года выбирается также и "Unwort des Jahres" - «антислово года», с 2001 выбирается «выражение года», а с 2008 - «молодежное слово года» [8].

В Великобритании акция «Слово года» (UK Word of the Year) проводится Издательством Оксфордского университета. В США акция «Word of the year» в США проводится различными организациями независимо друг от друга. С 1991 года проходит выбор «слова года» по версии «American Dialect Society» - Американского диалектологического общества (кроме того, выбираются ряд других номинаций - «самое бесполезное слово года», «самое креативное слово года», «эвфемизм года» и т. д.) [6]. С 2000 года выпускается топ-лист слов, фраз и имен года по версии агентства Global Language Monitor [4]. С 2004 года свой список «слов года» публикует американский лексиколог Грант Баррет в газете «The New York Times» [7]. Также с 2004 года акция проводится по версии Издательства Оксфордского университета («US Word of the Year») [5]; с 2006 года — по версии «Merriam-Webster» [3].

Стоит отметить, что в нашей стране в настоящее время выбор «Слова года» и «Неологизма года» осуществляется экспертным сообществом с предварительным отбором в Фейсбуке в номинациях: Слово года, Выражение года, Антиязык, Протологизм года.

Поскольку в английском языке существует несколько версий «слов года», нам представляется целесообразным рассмотреть ту версию, которая отражает экспертное мнение Издательства Оксфордского университета, поскольку эта версия представляет как британский, так и американский варианты английского языка.

Издательство Оксфордского университета, выпускающее Оксфордский словарь английского языка и многие другие словари, представляет свою версию «Слова года в британском английском языке» и «Слово года в американском английском языке», которые иногда совпадают. «Слово года» по версии этого издательства не обязательно появляется в течение последних двенадцати месяцев, но оно должно стать известным или общеупотребительным в этот период. При этом издательство не даёт гарантии, что «Слово года» будет включено в какой-либо словарь, выпускаемый им. В конкурсное жюри входят представители редакции каждого из словарей, выпускаемых издательством, а также лексикографы, консультан- ты и персонал редакции.

В данной статье для британского варианта «слова года» мы будем использовать обозначение $B r E$, для американского - AmE.

Начиная с 2004 года экспертная комиссия издательства выбрала следующие слова: 2004 - чав BrE\&AmE (chav - уничижительное прозвище определённой группы-в основном белых подростков, выходцев из рабочих семей, которые отличаются антисоциальным, агрессивным поведением); 2005 - судоку BrE (sudoku - числовой кроссворд ); подкаст AmE (podcast - звуковые или видеофайлы для распространения в информационно-телекоммуникационной сети интернет, образованное от слов iPod (айпод - цифровой аудиоплеер компании Apple) и broadcast (вещание по радио или телевидению); 2006 «бевпокойный» BrE (bovvered - авторский неологизм Кэтрин Тейт, ведущей популярного комического телешоу, происходящее от «bothered» («беспокойный», «встревоженный» ); с нулевым балансом выбросов углерода AmE (carbon-neutral - политика «углеродной нейтральности», компенсации вредных выбросов в атмосферу, неизбежных во время производства, которая предполагает, вопервых, внедрение технологий, которые минимизируют выбросы во время производства и реализации продукции, во-вторых, переход к использованию экологически чистых или переработанных материалов, в-третьих, высаживание новых деревьев); 2008 - кредитный кризис BrE (credit crunch - кредитный кризис - следствие длительного периода неосторожного и ненадлежащего, «токсичного» кредитования); «экономвождение» $\mathrm{AmE}$ (hypermiling- вождение машины, максимально оптимизируя расход топлива; 2009 - «всё просто» BrE (simples - слово, изначально появившееся в популярной телерекламе с участием сурикатов, говорящих с восточно-европейским акцентом, и получившее широкую известность в феврале 2019 года, когда премьер-министр Тереза Мэй на вопрос о Брекзите, ответила: «Если хотите, чтобы неопределенность закончилась, голосуйте за мой план соглашения (с Европейским Союзом). Simples»; разфрендить AmE (to unfriend - удалять из списка друзей); 2010 - «Большое общество» BrE (big society - идея политической программы Консервативной партии Британии с 2010 года, состоит в пересмотре роли государства в обществе); «отревегать» или «отверкаться» AmE (refudiate - авторский неологизм, употребленный губернатором Аляски Сарой Пэйлин, который она употребила в посте, призывая мусульман отказаться от планов строительства мечети, состоит из глаголов refute (опровергать) и repudiate (отрекаться)); 2011 - «сжатие среднего класса» BrE\&AmE (squeezed middle - ситуация ухудшения социального положения той части общества с низким или средним уровнем доходов, которая считается наиболее подверженной воздействию инфляции, замораживанию зарплаты и сокращению государственных расходов); 
2012 - полная неразбериха BrE (omnishambles - неологизм, образованный от латинской приставки omni- (все- лат.) и shambles (неразбериха); гиф (GIF (noun) AmE формат изображения для размещения в сети интернет, который может использоваться для создания анимации, и который породил целое направление изобразительного искусства за пределами инернета); 2013 - селфи BrE\&AmE (selfie); 2014 - вейп BrE\&AmE (vape); 2015 - ध эмоджи со слезами радости (Unicode: U+1F602) BrE\&AmE; 2016 - постправда BrE\&AmE (post-truth - обстоятельства, при которых объективные факты являются менее значимыми при формировании общественного мнения, чем обращения к эмоциям и личным убеждениям); 2017 «молодёжетрясение» BrE\&AmE (youthquake - значительные сдвиги в обществе в ответ на изменение вкусов и привычек молодежи); 2018 - токсичный BrE\&AmE (toxic - использовалось в разных значениях, начиная от «дела Скрипаля» (истории с попыткой отравления бывшего сотрудника российских спецслужб в Великобритании) до «токсичной маскулинности» (говоря о движении против домогательств \#МеТоо; 2019 - «чрезвычайная климатическая ситуация» BrE\&AmE (climate emergency) [5].

Анализ приведенных слов показывает, что на протяжении 15 лет проведения акции «слова года» в Великобритании и США совпадают девять раз и отличаются в шести случаях. При этом носителю русского языка для их понимания не требуется описательного перевода только для пяти из них, которые отражают явления, вышедшие на интернациональный уровень: селфи, вейп, подкаст, токсичный, чрезвычайная климатическая ситуация, постправда, гиф и судоку. Четыре слова относятся к совпадающим британскому и американскому вариантам, и лишь два - к несовпадающим. При этом надо отметить, что, несмотря на вхождение термина «постправда» в современный русский язык, оно, на данный момент, незнакомо абсолютному большинству его носителей и требует пояснений, как, впрочем, и остающееся околокомпьютерным термином слово «гиф».
Примерами неологизации путем вторичной семантизации могут служить: политика «углеродной нейтральности», кредитный кризис, Большое общество, «сжатие среднего класса». Они означают новые явления, свойственные только определенной социокультурной общности, поэтому только одно из них - «сжатие среднего класса» - принадлежит одновременно и британской, и американской версиям. Авторские неологизмы: «бевпокойный», «всё просто», «отказаться-опровергнуть» также имеют ярко выраженную национальную специфику и относятся только к одному из вариантов языка. К морфологическим неологизмам можно отнести слова: подкаст, разфрендить, полная неразбериха и молодёжетрясение. К этой же категории относится непереводимое на русский язык понятие «вождение машины, максимально оптимизируя расход топлива». Полным протологизмом является слово «чав», восходящее к цыганскому «чави», которым называли беспризорников. Исключительным случаем «слова года» стало эмодзи, которое выбивается из общего ряда и, на наш взгляд, не подлежит классификации.

Основными механизмами, на наш взгляд, является появление абсолютно новых слов в языке - лексических неологизмов и придание новых значений уже функционирующим словам - семантических неологизмов [2, с.97]. Одним из вариантов неологизмов являются протологизмы - новообразованные слова и выражения, вводимые в надежде, что они приживутся в языке. В отличие от окказионализмов - индивидуально-авторских неологизмов, созданных поэтом или писателем согласно существующим в языке словообразовательным моделям и использующихся исключительно в условиях данного контекста, протологизмы могут получают широкое распространение. В этом смысле «слово года», которое не получает вторичную семантизацию, может рассматриваться как протологизм, так как его выбор уже свидетельствует о широком распространении в языке, но при этом для понимания его абсолютно всеми носителями языка ещё требуется описательное объяснение.

\section{ЛИТЕРАТУРА}

1. Михайлова Ю.Л. Неологизация как элемент пополнения словарного состава английского языка XXI века / Ю.Л. Михайлова // Филологические науки. Вопросы теории и практики Тамбов: Грамота, 2017. № 9(75): в 2-х ч. Ч. 2. С. 129-131.

2. Михайлова Ю.Л., Михайлов М.Р. Аббревиация как способ слообразования неологизмов и развития лексического состава подъязыка компьютерных технологий (на примере английского языка) / Ю.Л. Михайлова, М.Р. Михайлов // Известия Волгоградского государственного педагогического университета. 2017. № 8 (121). С. 97-100.

3. Merriam-Webster's Words of the Year 2019 // Merriam-Webster, Incorporated : сайт. - 2020. URL: https://www.merriam-webster.com/words-at-play/word-ofthe-year/they (Дата обращения 10.11.2020).

4. Top Words of the Year // The Global Language Monitor : сайт. - 2020. URL: https://languagemonitor.com/category/top-words-of-the-уеar/ (Дата обращения 10.11.2020).

5. Word of the Year // Oxford University Press : сайт. - 2020. URL: https://languages.oup.com/word-of-the-year/ (Дата обращения 10.11.2020). 
6. Words of the Year // American Dialect Society : сайт. - 2020. URL: https://www.americandialect.org/woty (Дата обращения 10.11.2020).

7. Words of the Year // Grant Barrett : сайт. - 2020. URL: https://grantbarrett.com/words-of-the-year/ (Дата обращения 10.11.2020).

8. Wort des Jahres // Gesellschaft für deutsche Sprache e. V. : сайт. - 2020. URL: https://gfds.de/aktionen/wort-des-jahres/ (Дата обращения 10.11.2020).

( Михайлов Михаил Романович (mmichailov@mail.ru ), Михайлова Юлия Люсиевна (julia_mchailova@mail.ru ).

Журнал «Современная наука: актуальные проблемы теории и практики»

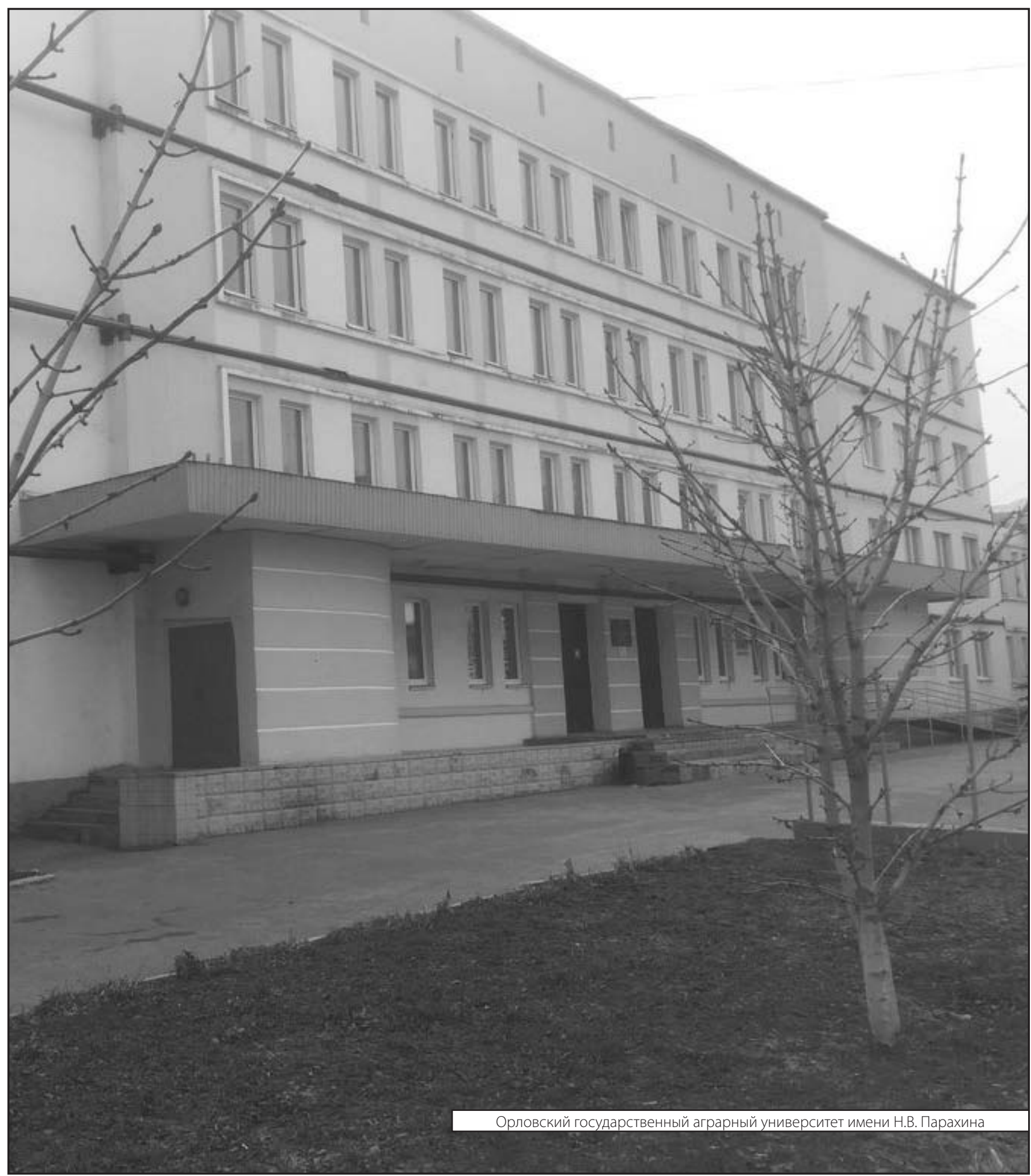

